\title{
Jiří Rajmund Tretera, Záboj Horák: Právní dějiny církví. Synagoga a církve v prüběhu dějin [Legal History of Churches, Synagogue and Churches yesterday and today]. Praha: Leges, 2019, 288 pp.
}

The new book is thematically and in terms of content closely related to two already published books by the same authors, both renowned canon law and religion law scholars: Konfesní právo ([Religion Law], Prague: Leges, 2015) and Církevní právo ([Church Law], Prague: Leges, 2016). From this point of view, the reviewed book is a logical completion of a scholarly-pedagogical work, the concluding instalment of a trilogy.

This very book is also related to the earlier publication by J. R. Tretera, Synagoga a cirkve kdysi a dnes ([Synagogue and Churches, then and today], Prague: J. Krigl, 1994). In comparison with the recent book, however, the current publication documents significant development of research and pedagogical experience over a quarter of a century.

It is obvious that if the book was primarily intended only for students of theological disciplines, it could pay much more attention to the legal issue itself in the narrower and technical sense, since theologians obtain information about many facts mentioned in the book in other subjects or it would be assumed that they already have this knowledge. Yet, the degree of secularisation in the Czech Republic is such that the benefit for a wider audience can be guaranteed precisely by the approach of the authors, who explain the very realities of the Christian religion in some parts of the presented publication. The book thus becomes an interdisciplinary work, dealing with the basics of theology, biblical studies, history of the Church 
and the Jewish synagogue; the effort of the authors to instruct the reader with relatively detailed geographical data is very evident.

The approach of the authors is quite methodical; they deal, for example, with etymological and spelling issues concerning ecclesiastical terminology. In this basic context, issues related specifically to Church law and, to a large extent, religious law are also presented. It should be noted that in the Czech specialised or popular literature, some experts focus solely on Catholic canon law, while the approach of the authors is broadly ecumenical. There is also a focus on Orthodox or the Reformed Churches, and at the same time the development of Jewish law is included as an integral part of the book, which clearly emphasises the inner connection between Judaism and Christianity.

In matters of the relationship between Churches and the state, the authors clearly give priority to the autonomy and independence of the former as well as of synagogues and their right to resist any oppression from the state.

The core of the book consists of two parts of unequal length. The first is shorter, divided into five chapters, and discusses the legal history of Israel from the very beginning to the establishment of the Roman rule. The second part, far more extensive, deals with the Church and the Synagogue from the first to the 21st century and is thus divided into 21 chapters, each of which deals with one century.

The authors deliberately decided not to have separated the history of Judaism from the history of Christianity; thus, the second part of the book combines the history of Christianity with the development of Judaism. For example, the Amoraites, the interpreters of sacred Jewish texts from the 3rd century AD appear between the decrees of the popes of the 3rd century and the writings of Origen (p. 119). The authors do not avoid the sensitive issue of Christian anti-Semitism, for which, according to them, anti-Judaism is a more appropriate term (p. 30), and add: "Public resistance to the Church and thus to all Christians has become similar in intensity in recent decades to anti-Semitism" (p. 31).

The description of the foundations of Christianity is in some places even typical of confessors - Mary is "in the tradition reverently called the Virgin Mary" (p. 66), Jesus' miracles are listed as unswerving facts (“Jesus thaumaturgos" - p. 71), because so the Church teaches, and canon law is in consistent relation to the teaching of the Church. Therefore also Jesus' twelve apostles are described as "the beginning of the hierarchy" (p. 72).

On the page 95, the section of the book having much in common with the genre of so-called biblical history concludes and the story of the Church of the first centuries begins to be described, bringing the subject closer to Eusebius' Church History and the successors of this historically 
first written work on history of the Church. Of course, the authors pay special attention to legal monuments, especially the gradually increasing number of decrees of popes and the canons of synods and councils. They do not neglect the charismatic element of the Church, operating through religious orders, either.

The authors also analyse the relationship between the Church and state power, as well as interfaith relations, century after century. I find particularly interesting the following statement by the authors: "Nestorians and Monophysites, initially often welcomed (Arabic, resp. Islamic) occupation as a release from the Byzantine yoke. What a self-deception it was!" (p. 156).

The Czech lands enter the scene from the page 164 onwards, so the missionary work preceding Saints Cyril and Methodius is already included in the overall context of ecclesiastical legal history. Then, close attention is paid to the work of Saints Cyril and Methodius and the fate of the first Czech saints, Ludmila and Wenceslaus. Jan Hus and the Hussite movement (pp. 191-192) are also discussed.

The description of conditions in the medieval Church includes appreciation of the Church for the ban on ordeals (p. 182), but also information on the origin and effect of the Inquisition (pp. 182-184). A relatively extensive passage is dedicated to the Protestant Reformation (pp. 198-211). The authors evaluate the French Revolution with its excesses rather critically (pp. 226-229). Bismarck's so-called culture struggle against the Catholic Church is also denounced, and the authors find that it was carried out "contrary to its name, as a considerably uncultured act" (p. 238). It is only logical that the authors condemn the horrific actions of the totalitarian regimes of the 20th century, the Soviet Russia from its beginnings (1917) and in the time of the Soviet Union (1922-1991), as well as Nazi Germany (1933-1945).

The current century, which has passed by only one fifth, is described in the chapter 21 (pp. 271-274) with particular emphasis put on three aspects of development of Churches that the authors consider to be the main tendencies: great expansion of categorical pastoral care to the nonChurch sphere, spreading the Christian faith in America, Africa, and Asia, as well as reducing the gap between popular and confessional Churches: "Confessing revival Churches in many countries, such as the Czech Republic, are growing in both the number of their members and local congregations. This is due to a certain degree of aridity of the society that previously turned irreligious, where a part of non-believers, who are not members of any church, seeks new religious experiences. In addition to the Protestant and Eastern churches, the religion of South Asian origin is also growing. There is a growing interest among Catholics in the 
older form of the liturgy" (p. 272). Numerous amendments to the codes of canon law (pp. 272-274) are mentioned as important ecclesiastical events of this century.

The book is not overloaded with quotations that would make the text incomprehensible, but even so the list of sources contains 26 items, secondary literature is represented by 86 items, while the most mentioned works were written by Professor Antonín Ignác Hrdina (Prague). Of course, there are also foreign publications, namely Polish, German, and English. There is also a factual and nominal register.

The publication Legal History of Churches as the culmination of the co-author's book trilogy may, with its far-reaching perspective, serve a wider group of readers. Primarily, it will certainly attract attention of the legal community, especially those who deal with the Church life and need to know their internal regulations. The authors involve them in the historical and ideological matrix, from which the law-making activity of the Churches originates. And last but not least, the book has a chance to become a convenient study aid for students of law and humanities.

Stanislav Přibyl

(1) https://orcid.org/0000-0002-2470-1405

Translated by Marek Novák 